\title{
スポーツマン形質の Allomorphosis
}

\author{
服部桓明
}

（昭和51年8月 3 日 受付）

\section{On the Allomorphosis of Anthropometrical Dimensions on Athletes}

\author{
Komei Hattori \\ (Tokyo University of Agriculture and Technology)
}

Number of reports concerning the physique of the various athletes have been reported. The present study aims to clarify the interspecific allometry relation among several sports categories, because the analysis by allomorphosis has not been previously attempted.

The materials used in this study are anthropometrical data of the athletes on 15 sports categories in male and 9 sports categories in female from the Report of Physical Fitness Tests on the Representative Athletes of Japan in Universiade Summer Event (1967) published by the Japanese Amateur Sports Association.

In double logarithmic grid papers to indicate the allomorphosis relations, stature is taken as abscissa $(x)$ and the other 5 items are ordinate $(y)$. Straight relations (tribes) are drawn paralleled to the regression lines to indicate the relative variations on non-specially trained young peoples (Hattori and Sawaki, 1971).

From the results indicated as the scatter diagrams on $\log -\log$ papers (Figs. $1 \sim 10$ ), the findings are summarized as follows. In body weight, the heavier class in Judo has a tendency to be biased to the higher tribe than the lighter one. Gymnastics in both sexes locate lower tribes nevertheless they have conspicuous muscular types on physique. In sitting height, sole tribe can be identified. In chest girth, fencing, volleyball and basketball in male situated the lower tribe, on the other hand long distance run and gymnastics in male and swimming in female transit to higher tribes in comparison with the result of body weight. Swimming in both sexes show relatively (allomorphosis point of view) large forearm and small upper arm and reverse relation can be observed in tennis players.

(Komei Hattori : On the Allomorphosis of Anthropometrical Dimensions on Athletes, Jap. J. Phys. Educ., Vol. 21, No. 4, Dec., 1976, pp. 217 224) 
スポーツマンの形算が非鐉練者に比し，より発 達してていることは，すでに幾つかの報告によって 明ら斾にされてきている (Correnti, 1960"); Montoye, $1967^{12)}$ ). この爱は持綕的な運怔刺激のため 二次的に形成された適応晊集之生来の適性に基つ く要素が加味したものと考えられる。身長等は生 来的な要素が強いと考えられるが (Furusho, $\left.1974^{3}\right)$ ，部部量が比較的多く関与する测度では， 非対称性の刺激に由来する形質の左右差に関する 報告などす多く，適性化の傾们がつよいといえよ

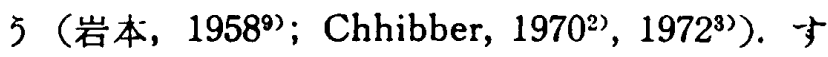
なわち刺激の受容量と淘汰の著しい，いわゆる一 流選手には適応，適性の寄与の度合は異にしつつ む，その種目固有の形質が観察されるものと考え られる。

種目間の形貿の近似性や差異についての検討は 主として絶対量の差や 2 测度間の比の比較等によ りなされている（大柣，192818); 吉田，193322；

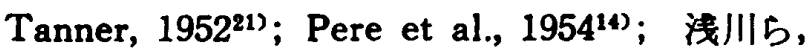
$1956^{1)}$; 下条, 1959(0); 白井, 195920); 勝木ら, $1965^{10)}$; 小林, 1968 ${ }^{(1)}$; Schreider, 1968 ${ }^{16)}$; Poledmak, 1975'5). 一方ヒトの 2 形間の変異には 種内あるいは種間の場合を問わずに，それそれの 対応において固有の関係のあることが知られてい る. 身長一体重の関係についてい5ならば，身長 䧂級が大となるにつれ，体重の比种が大きくなる のは周知のことであり（服部，1973年），異なった 身長陼級間で等しい体重をるつことは，すでに等 買でないことを意味している。

対応する 2 測度の䎦対量が 2 集団において異な る場合，それらの 2 测度間関係が集団間で近似し ているかど5かを判断するには，2 変量の座標点 がつくる集団間の並びをみるのが便利であろう. これは上記の身長一体重関係の例のよ5に直楾的 な配列を示すとは限らないむむしろ直楾の場合む 含む多次元関係として表わすのが妥当であろ5. この方法は Huxley と Teissier (1936) ${ }^{8}$ によっ て提唱された Allometry 分析中の interspesific allometry (allomorphosis) と呼ばれるもので, ヒトを含めた生物の様々な変翼によく適合する方

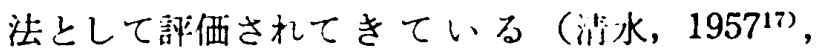
$\left.1959^{18)}\right)$.
Allometry 式 $\left(y=b^{\alpha}\right)$ は雨迅を対数变換すれ ば $\log \mathrm{y}=\log \mathrm{b}+\alpha \log \mathrm{x}$ として示され，変量 $\mathrm{x}$, $\mathrm{y}$ の対数值をと机证 $\alpha$ 值がいかなる場合にも直 楾関係が得られることになる.

本研究ではスボーツ種目集団がそれぞれ活有の 形質を有するところから，こ机らの形質間の生物 学的な近似性や特翼性を示すため，いまた検討さ れていない、 allomorphosis 分析の適用を試みた。

\section{筫料と方法}

料は 1967年ニニハシシフード夏季大会日本代表 選手体力測定結果（日本体育協会・スポーツ科学 委員会）から男15種目，女9種目に関与る測定值 の平均值を用いた（Table 1)。それぞれの種目 は，つぎのような略号によって表わしてある。す なわち陸上競技短距崔（Ts），陸上競技中曼距崔

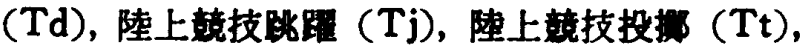
体操 (G)，柔道怪量級 (JI)，柔道中量級 $(\mathrm{Jm})$, 柔道重量䄲 (Jh)，フェンシング (F)，テニス $(\mathrm{Te})$, バレーボール (V), バスケットボール(B), 水泳競永（S)，水泳飛込 (D)，水球（W）であ ろ. 各種目ごとの例数，および分析の対象とした 6 項目（身長，体重，座高，胸囲，上解最大囲， 前放最大团）の平均值は Table 1 のとおりであ ろ.

Allometry 式 $\mathrm{y}=\mathrm{bx}^{\alpha}$ の基線 $\mathrm{x}$ には身長をと ク，他の测度をyとした，それは相対变異研究で は総合的な指标である身長を基線とするので取も 一般的であるためである.

Allomorphosis 研究において直線関係を示して 配列するプロットのまとまり（tribe）が複数想定 される場合には，料集団から求められる回諦直 線は検討の対象とする種目の種類や数によって変 動することが考えられ基隼となりにくい，そこで 基策の tribe は服部ら（1971）により報告されて いる一般青年（18歳）の相対変異式とし，Fig. 1 〜Fig. 10 において太実線で示してある. すなわ ち同じ tribe 上に位置するものは 2 测度間の生物 学的な関係に共通性や近似性があるといえる。一 万、それぞれの種目が林研究の㭘討の対象となっ た男15種目，女 9 種目間でどのよ5な形質の相対 的位置を占めるかを知るため，Table 2 に今国の 
Table 1 A part of the table of mean values of six items in each sports category cited from the Report of Physical Fitness Tests on the Representative Athletes in Japan in Universiade Summer Event (1967)

\begin{tabular}{|c|c|c|c|c|c|c|c|c|c|c|c|c|c|c|c|c|}
\hline \multirow[t]{3}{*}{ ? $\cdots$} & \multirow[t]{3}{*}{$\cdots \cdots$} & \multicolumn{8}{|c|}{ Male } & \multicolumn{7}{|c|}{ Female } \\
\hline & & & \multirow{2}{*}{$\mathbf{N}$} & \multicolumn{6}{|c|}{ Mean values $\mathrm{mm}$} & \multirow{2}{*}{$\mathbf{N}$} & \multicolumn{6}{|c|}{ Mean values $\mathrm{mm}$} \\
\hline & & & & $\mathrm{ST}$ & $\mathrm{BW}$ & $\mathrm{SH}$ & $\mathrm{CG}$ & $\mathrm{GU}$ & GF & & ST & $\mathrm{BW}$ & SH & $\mathrm{CG}$ & $\mathrm{GU}$ & GF \\
\hline \multirow[t]{4}{*}{ Track \& Field } & sprint & Ts & 12 & 1727 & $65 !$ & 922 & 893 & 251 & 243 & 5 & 1621 & 564 & 864 & 816 & 250 & 229 \\
\hline & distance & $\mathrm{Td}$ & 9 & 1680 & 571 & 899 & 870 & 237 & 235 & $\cdots$ & & & & & & \\
\hline & jump & $\mathrm{Tj}$ & 7 & 1748 & 653 & 925 & 907 & 265 & 256 & i & 1663 & $59 !$ & - & 830 & 247 & 228 \\
\hline & throw & $T t$ & 6 & 1775 & 834 & $97 !$ & 1011 & 317 & 293 & 4 & 1653 & 693 & 896 & 912 & 280 & 251 \\
\hline Gymnastics & & G & 6 & 1634 & 570 & 884 & 887 & 290 & 262 & 6 & 1535 & 487 & 837 & 804 & 236 & 219 \\
\hline \multirow[t]{3}{*}{ Judo } & light weight & $J$ & $\vdots$ & 1660 & 667 & 905 & 929 & 291 & 266 & - & & & & & & \\
\hline & middle weight & $\mathrm{Jm}$ & 4 & 1777 & 822 & 948 & 985 & 329 & 292 & - & & & & & & \\
\hline & heavy weight & Jh & 4 & 1797 & 1001 & 959 & 1068 & 349 & 308 & - & & & & & & \\
\hline Fencing & & $F$ & 11 & 1718 & 615 & 923 & 845 & 253 & 254 & - & & & & & & \\
\hline Tennis & & Te & 3 & 1703 & 617 & 892 & 891 & 262 & 267 & 4 & 1583 & 551 & 855 & 822 & 254 & 239 \\
\hline Volleyball & & V & 11 & 1750 & 700 & - & 860 & 269 & 252 & 11 & 1690 & 680 & - & 876 & 270 & 248 \\
\hline Basketball & & B & 12 & 1837 & 780 & 975 & 915 & 270 & 263 & 12 & 1643 & 613 & 886 & 839 & 250 & 235 \\
\hline Swimming & & $\mathbf{S}$ & 18 & 1718 & 686 & 935 & 963 & 296 & 262 & 12 & 1617 & 555 & 879 & 874 & 262 & 235 \\
\hline Diving & & $\mathbf{D}$ & 4 & 1650 & 589 & 902 & 895 & 274 & 256 & 4 & 1581 & 528 & 859 & 833 & 261 & 230 \\
\hline Water-polo & & $\mathbf{W}$ & 9 & 1727 & 709 & 921 & 981 & 306 & 269 & - & & & & & & \\
\hline
\end{tabular}

ST : Stature, BW : Body weight, SH : Sitting height, CG : Chest girth, GU : Girth of upper arm, GF : Girth of forearm

data に基つく回帰分析の結果を，またその回彎 直線は Fig. 1〜Fig. 10 の中に点線によって示し てある。

\section{结果と考家}

1. 体重：身長一体重の関係では Fig. 1 に示 してあるよ5に，男では扰よそ5つの Allomorphosis 群が区分できる。すなわち，最も上位の tribe に Jh が独立し，つきの tribe に $\mathrm{Tt}$ と $\mathrm{Jm}$ が，ついて B, W, S, Jl が同一の群をつく， ている，第 4 番目の一般青年の Allometry 関係 と近似して配列するものには, $V, T j, T s, T e$, D, G があり，やや下って Td がある.

このよ5に柔道では, 柽, 中, 重量級と段階的 により上位の tribe へ移行している.このことは 重いクラスはと身長に相応する以上の重量が要求 されているためと芹えられるか，このことが隹

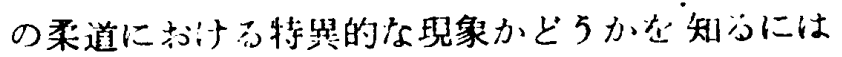

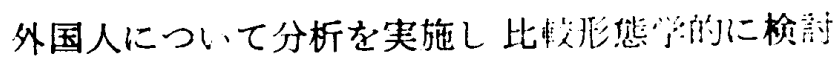
ナる必要があるが，重量制の 1 つの間题を示唆け
るものといえよ5.

つぎに女子の場合であるが, Fig. 2 にみられる よ5にTtが最上位の tribe に独立し，VとBが これにつぎ，Tj,Ts, S, D, Ts が同一の tribe を つくっている，G は最下位に位置するが，男の場 合も比較的下位の tribe に含まれていた傾向と一 致する。すすなわち，体操が低身長と良好な筋の発 達を形態的特徵としている点から上位 tribe に位 置するのではないかとい5予想に反する傾向を示 した。これは体操選手の皮脂厚量の娍少に関係し ていると洘えられる。

2. 座高: Fig. 3 と Fig. 4 に男女の結果が示 してある、いずれあほ活単一な tribe となってお り，種目による身長一座高の Allomorphosis 関 係に大きな差は認められないことを示している. 幾分罗の Ft 方上位に， Te が下位に傾いており， 相刘的にそれぞれ高伖高，低座高であることが知 x心.

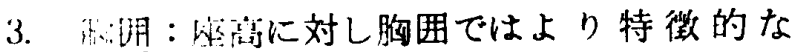

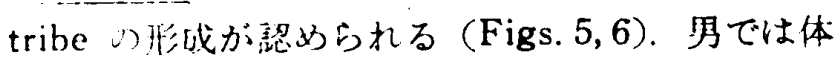




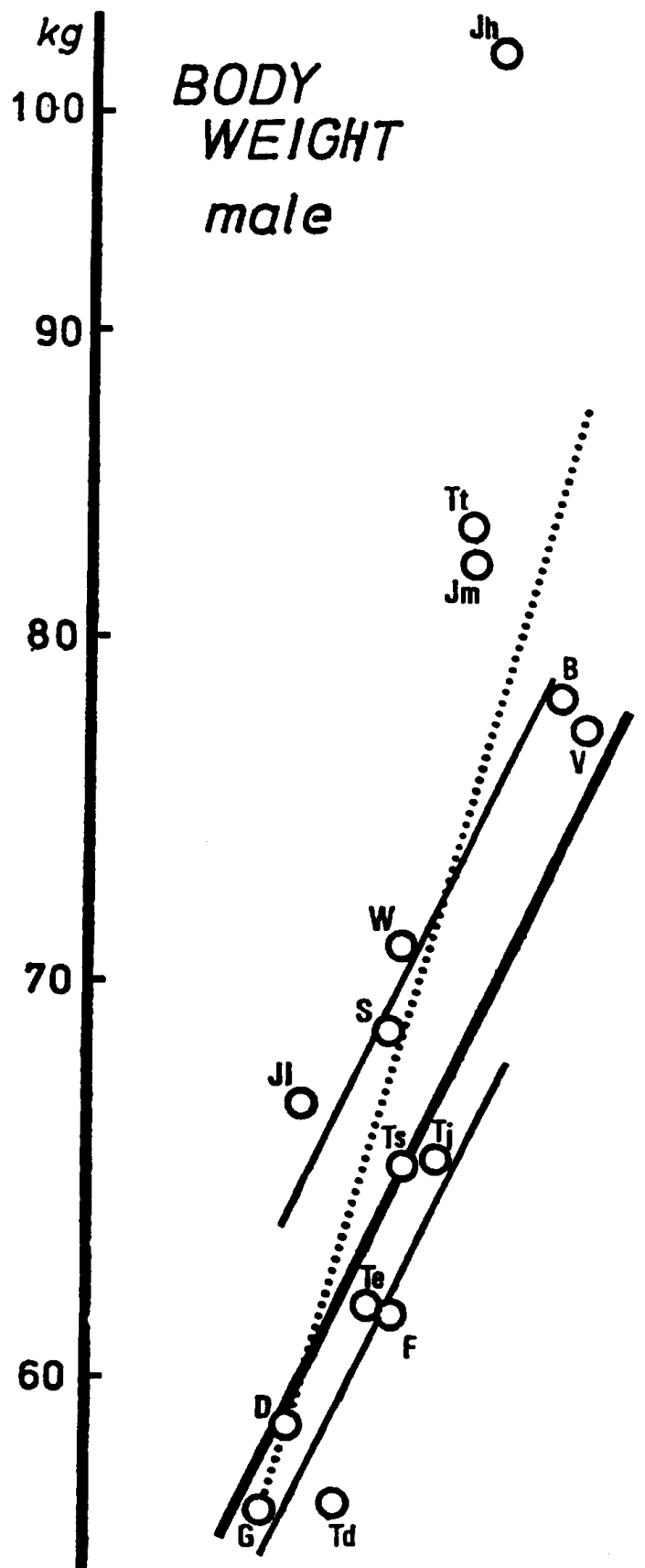

STATURE
160
170
$190 \mathrm{~cm}$

Fig. 1 Body weight against stature in male; logarithmic plotting. Thick line shows the standard tribe calculated by Hattori et al. (1971), and thin lines parallel to standard tribe are other ones. Broken line represent the regression line on Table 2.

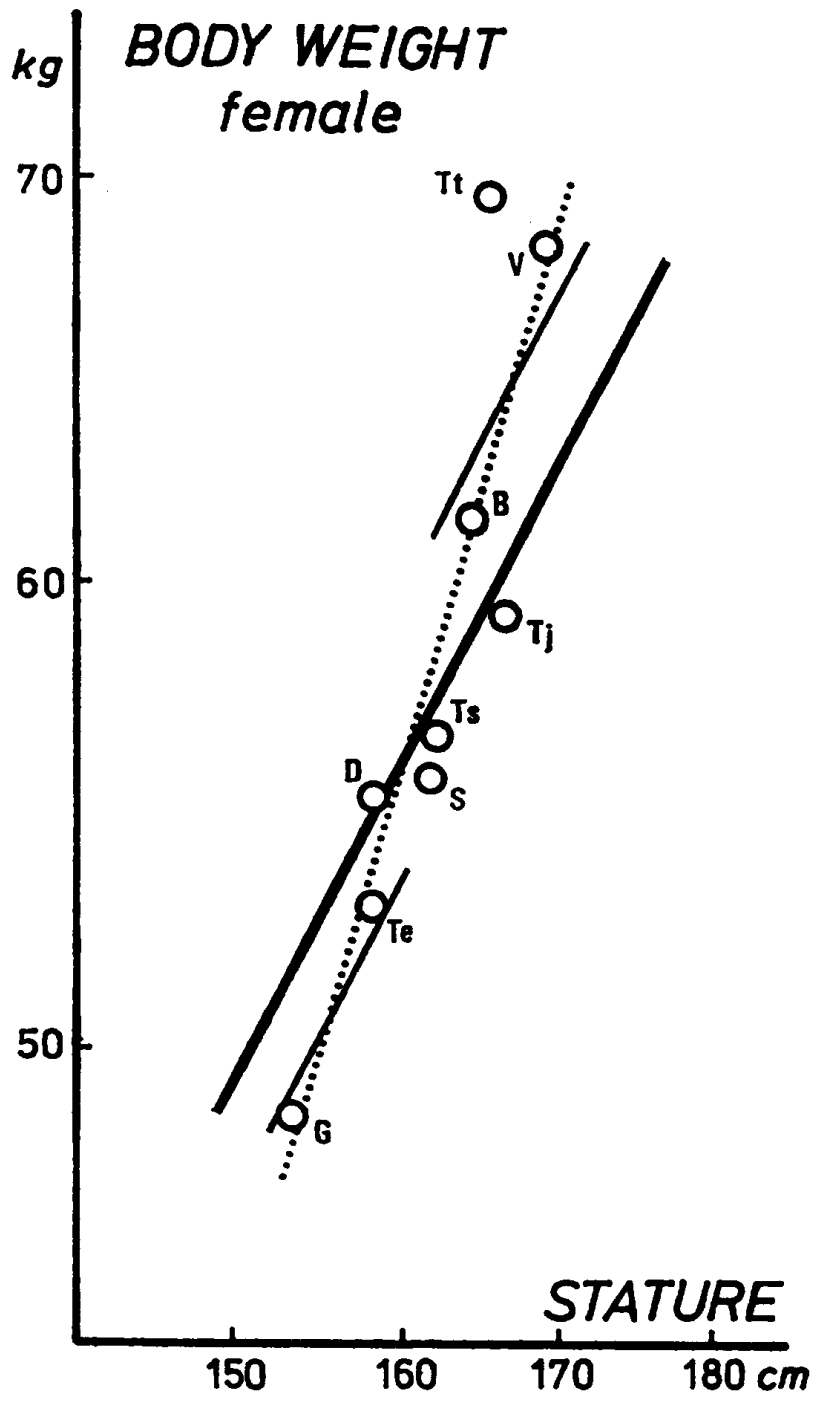

Fig. 2 Body weight against stature in female; logarithmic plotting

Table 2 Allometry coefficients $(\alpha)$ and logarithmic values of constant $b(\log b)$ of five items against stature using the mean values of the sports' categories dealing with this paper

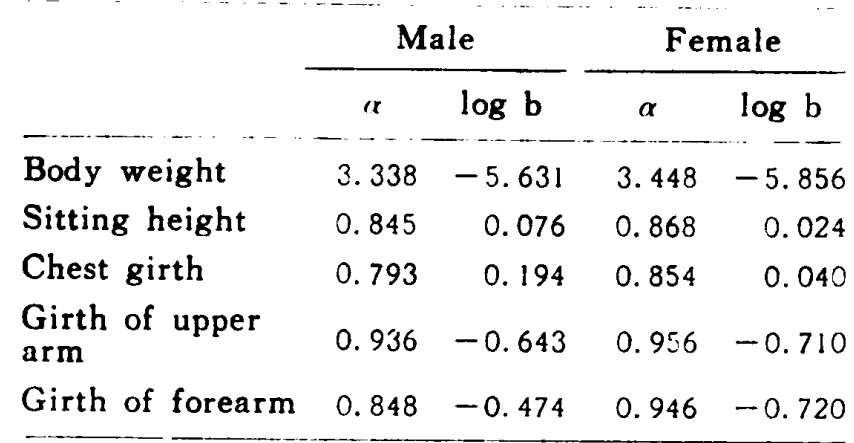




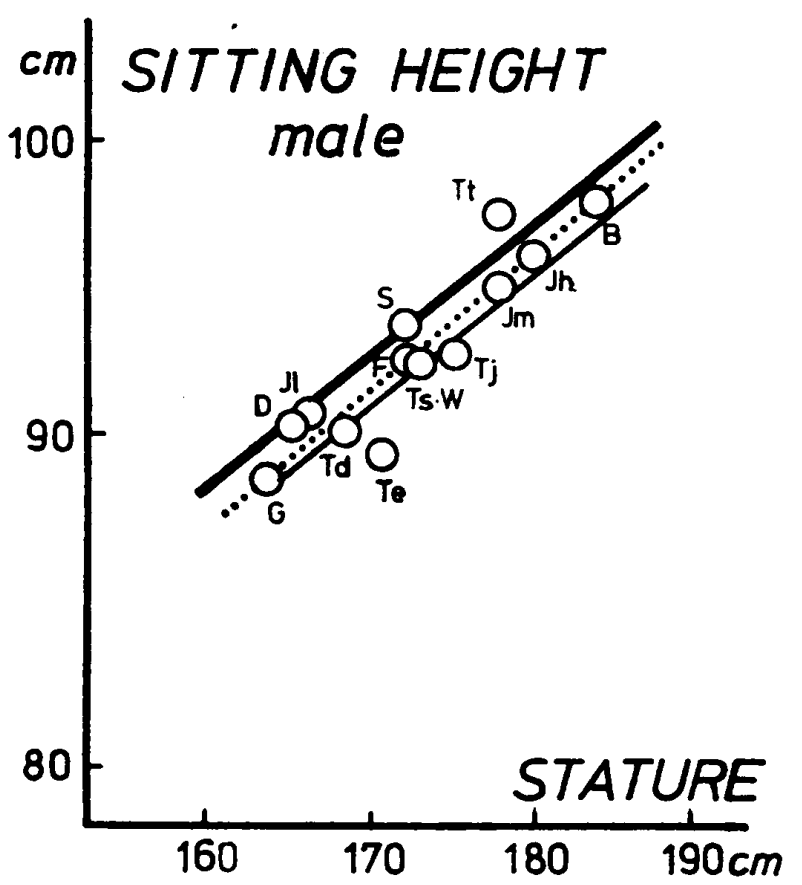

Fig. 3 Sitting height against stature in male; logarithmic plotting

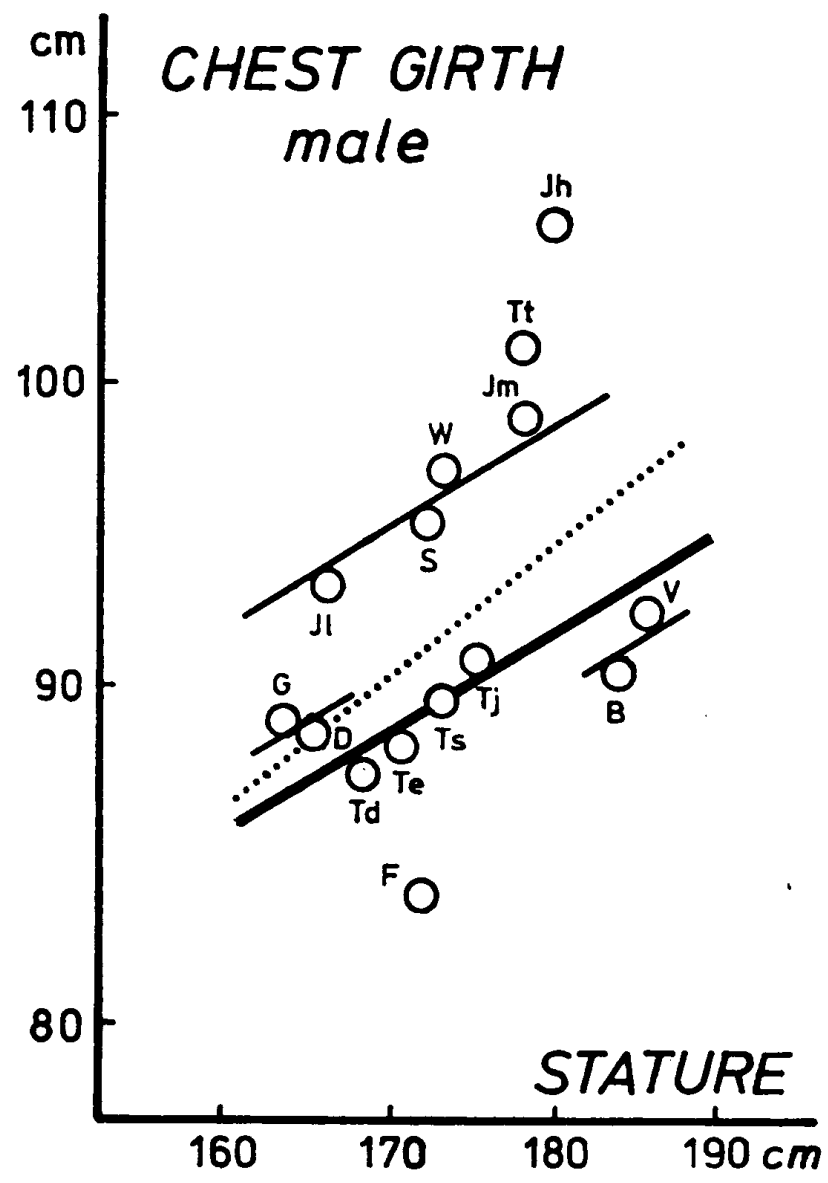

Fig. 5 Chest girth against stature in male; logarithmic plotting

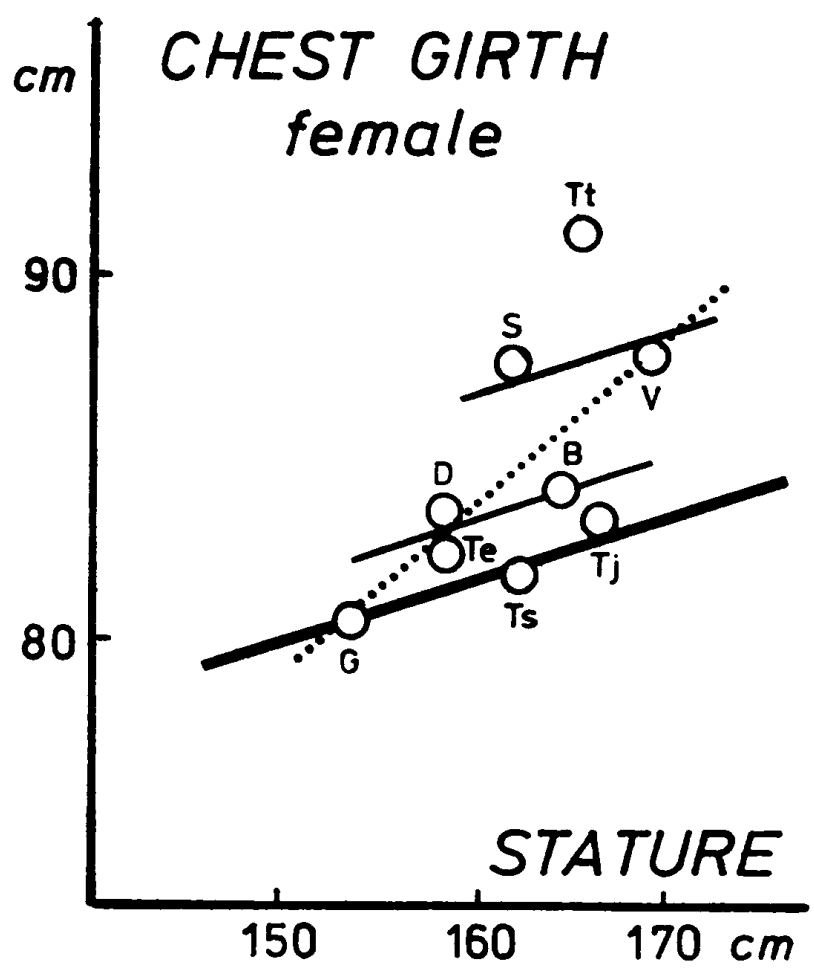

Fig. 6 Chest girth against stature in female; logarithmic plotting 


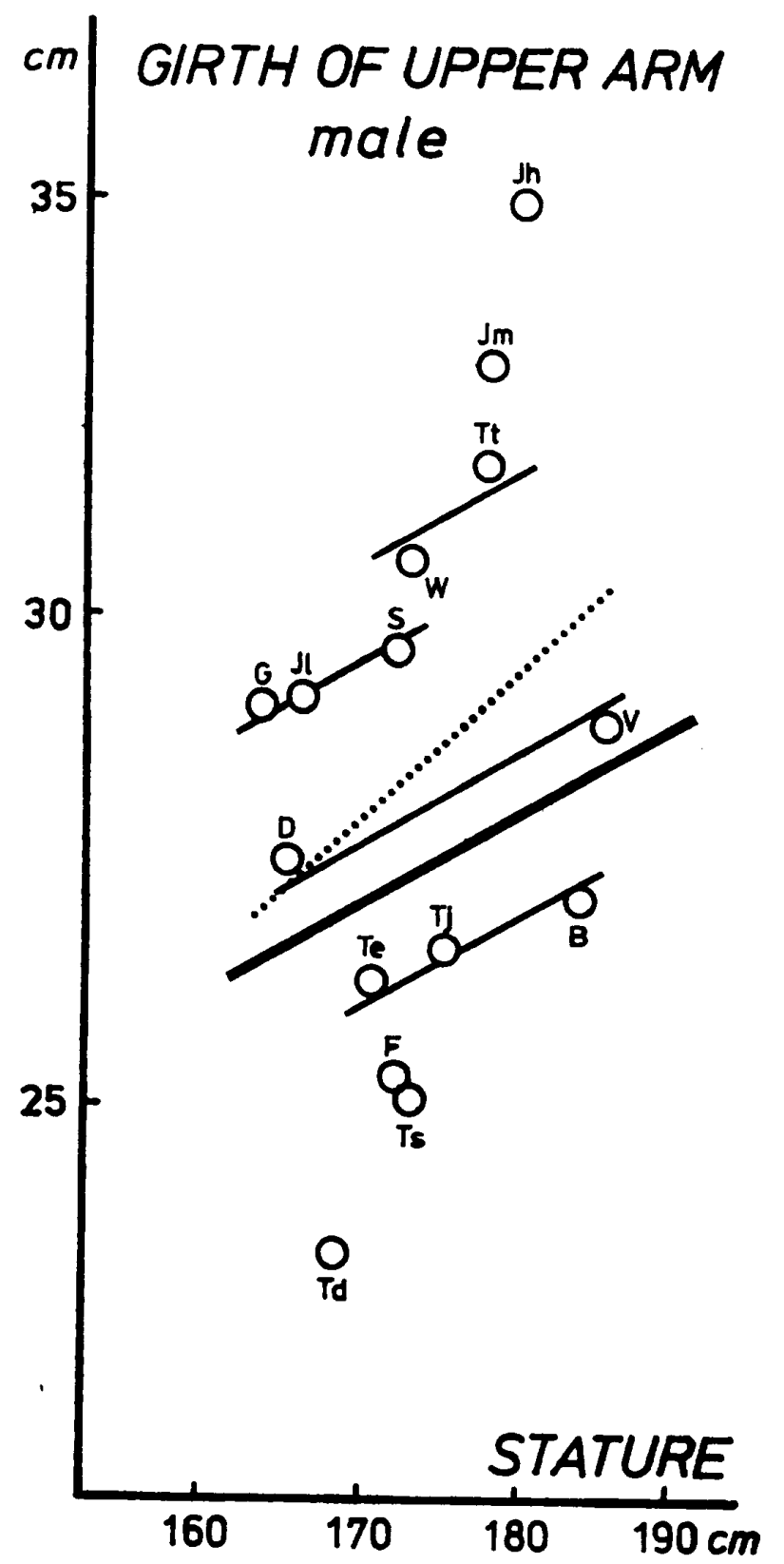

Fig. 7 Girth of upper arm against stature in male; logarithmic plotting

重において上位の tribeに位置していた V，B は 一般青年による太線の回帰直線よりも下位へ移行 している．F は単独で最下位の tribe となり，身 長との相対的な関係でみるとき狭胸型であること を示している，一方，体重で最下位の tribe にあ った Td は中間のそ机に移っており，商い肺機能 を必要とする持久走の特惟が胸囲に示されている とも考えられる．G むまた上位へ移行している。

女子では， tribe は4つに分けられ，体重の場 合に比し $S$ の上位 tribe への移行が著しい特徵

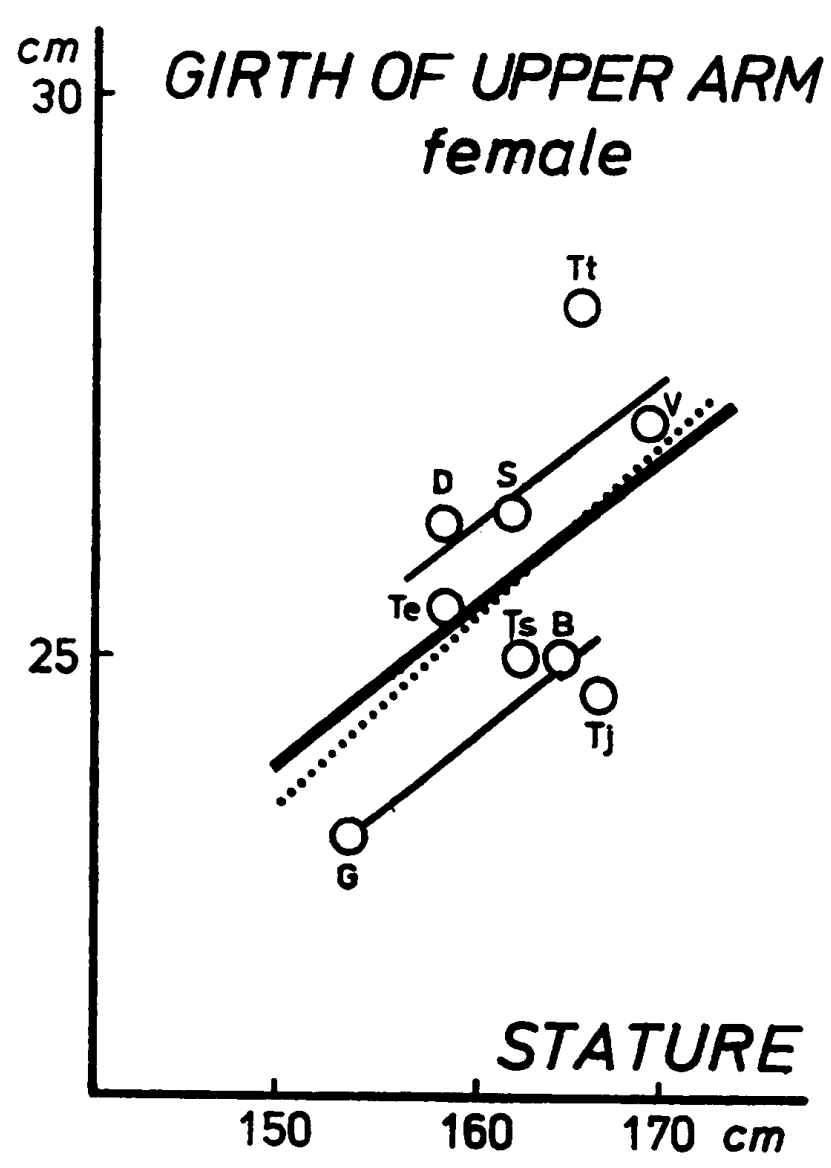

Fig. 8 Girth of upper arm against stature in female; logarithmic plotting

となっている，一般青年に比する，身長に対する 体重と，はるかに大きな胸囲が競泳塄手の形贸的 特徽といえよ 5 。

4. 上腕最大囲：Fig. 7 にみられるよ5に，男 では 8つの tribe をつくっており，上位より Jh， $\mathrm{Jm}, \mathrm{Tt}$ と W, S. Jl と G, V と D, B. Tj と $\mathrm{Te}, \mathrm{F}$ と Ts およひ Td である. このよ5に程 目の特徽が影著で一般に上的の使用の著しい理目 が上位 tribe に位置しており，適性化の生じやす い測度といえよ5．Jh と Jm は著しく大きい上腕 囲をもつ集団といえよう．G が基本の回帰線より 上位に位目するのは当然ながら， Te がそれより 低くなっているのは興味深い，Td は顕著に低い tribe をつくるのも，この種目の運動様式に由来 ナるものであろ5。

女でも全体としてほぼ同様な傾闪を認めるが， $\mathrm{Te}$ と $\mathrm{G}$ との関倸は列の場合と反対で，Gはより 低位の tribe に含まれている (Fig. 8).

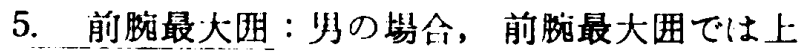




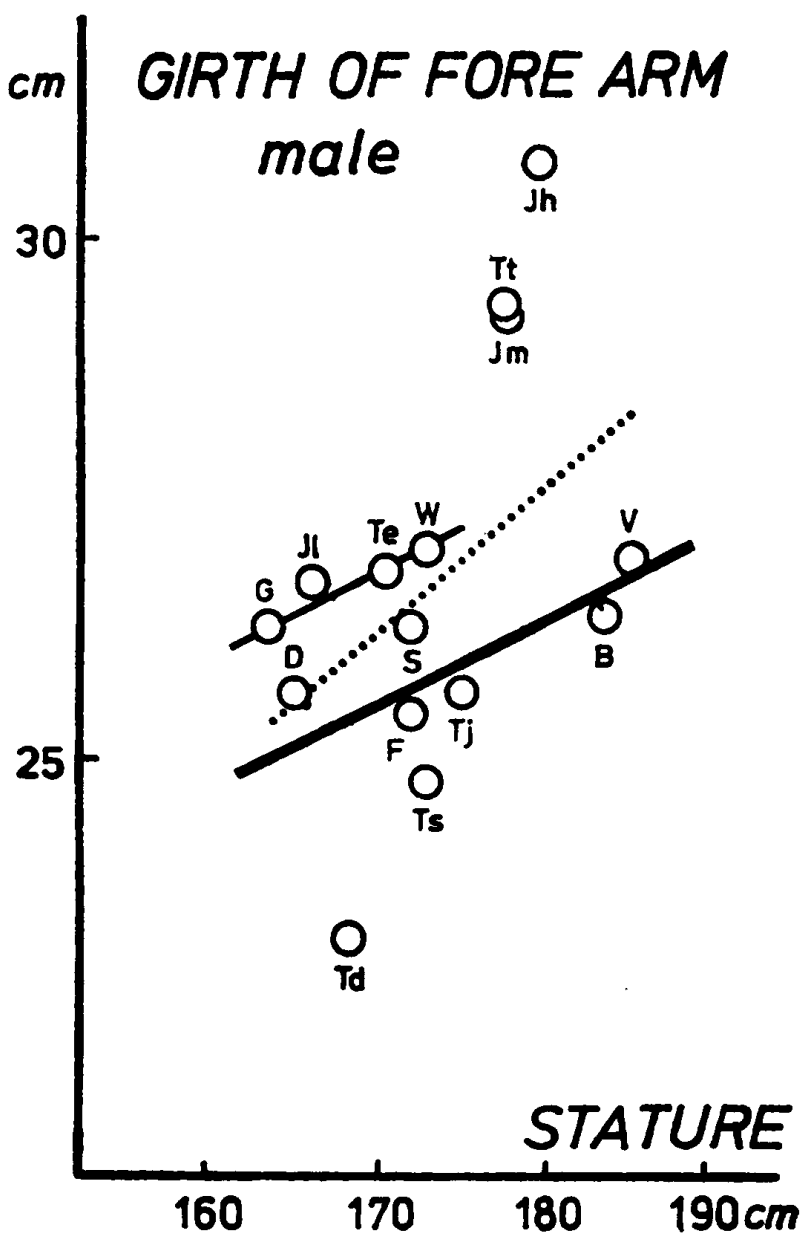

Fis. 8 Girth of forearm against stature in male; logarithmic plotting

樎最大进の場合に近似するが，tribe はよりまと まっているといえよう(Fig. 9). 特徽的なのは上 腕最大囲では $\mathrm{B}, \mathrm{Tj}$ と同じ tribe であった $\mathrm{Te}$ か：W，Jl，G とともに上位の tribe を形成する 点である. 生物学的な均勢からい5なら,テニス 選于の上腕は一般青华と近似するかやや細く，前 靘は明眿に太いといえよ5。

上腕最大囲において $\mathrm{G}, \mathrm{J}$ l と同一の tribe に あった S はやや下位へ移行する、すなわち，竸 泳では前腕上り上腕で相対的発達がよいと思われ る.

女の前腕最大用では $\mathrm{G}$ が上腕最大囲の場合と 同様に最下位の tribe に位置しており，体操選手 の上肢周径は，Allomorphosis の上で男では太く 女では練いとい5傾向をあらわしている（Fig． 10).この理由は上肢使用に基つく適心か，男で は筋の発達として量的に顕在化し，一方，女では 筋の発達をしのぐ皮下脂肪量の減少によるためと

\section{$\mathrm{cm} \mid \begin{gathered}\text { GIRTH OF FORE ARM } \\ \text { female }\end{gathered}$}
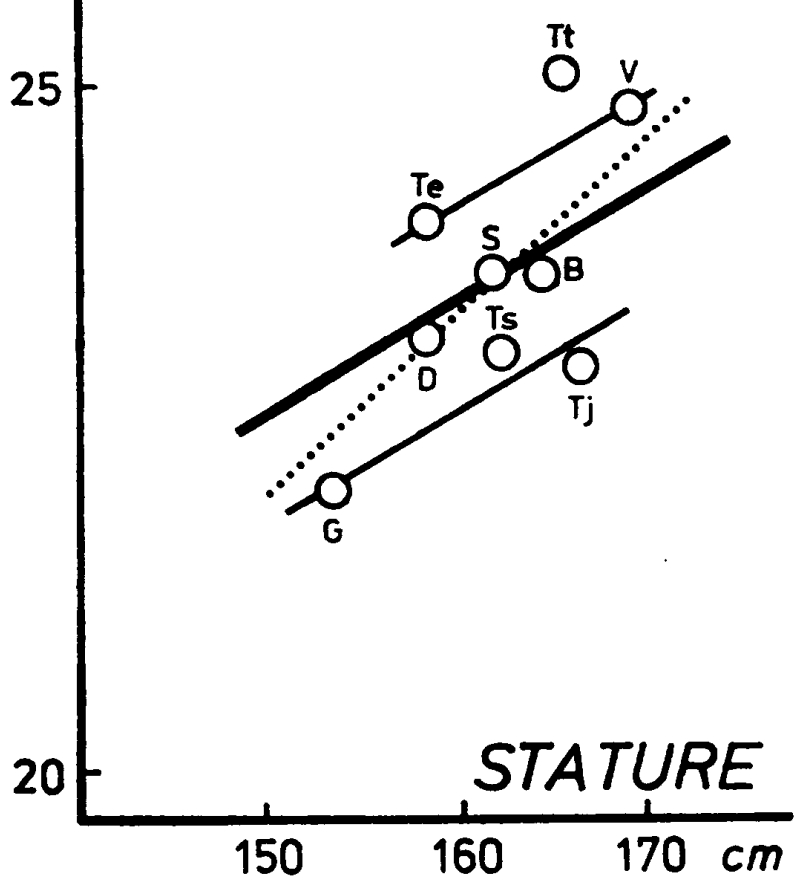

Fig. 10 Girth of forearm against stature in female; logarithmic plotting

推定される。

上㤏最大囲と比較し $\mathrm{Te}$ か上位に $\mathrm{S}$ が下位 tribe に移行する傾问は，女です男の場合と同様であ り，水泳は太い上腕の群に，テニスでは太い前踠 の群に属しており，運動形態の特徽が反映してい るといえよ5。

\section{雪約}

スポーッ種目間の形質の特徽を明らかにするた め,基線を身長とし 5 項目（体重，座高，胸囲，上 腕最大囲, 前腕最大囲) の Allomorphosis 分析 を実施した。得られた Allomorphosis 関係は Fig. 1 Fig. 10 にみられるとおりであるが、こ の結果に基づく考察から特徽的な点を列記すると 以下のとおりである.

1. 体重では，柔道（男）の重い階級はどより 上位の tribe 一移行する。体操では男女とも下位 tribe に位異与る。

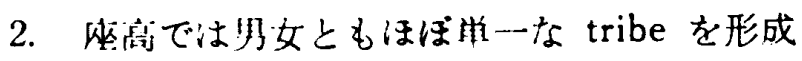
し，種目閏の管は大きくない。 
3. 胸囲では男のフェンシング，バレーボル，ハスィットボールが下位 tribe に位置し，陸 上: (長距磪)，体操は体重との Allomorphosis 関 係の結果に比べ上位 tribe へ移行する，女では 水涾が体重の場合に比し上位 tribe 一移行する.

4.上腕最大曲では男で 8 つの tribe に分かれ る.テニスでは一般青年による|情線より低い。 女の体操はテニスより低い tribe に位置する。

5. 前棜最大囲において，男のテニスはレスリ ソグや体操と同じ tribe に位置し，女では体操が 最下位 tribe をつくる.

\section{文新}

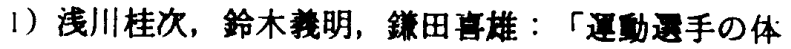
势次つて」体力科学, 5, 165 176, 1956.

2) Chhibber, S. R. and I. Singh : "Asymmetry in muscle weight and one-sided dominance in the human lower limbs", J. Anat., $106: 553$ 556, 1970.

3) Chhibber, S. R. and I. Singh : "Asymmetry in muscle weight in the human upper limbs", Acta anat., 81: 462 465, 1972.

4) Correnti, V. : “Untersuchungen uber die Somatologie der Sportler", Z. Morph. Anthrop., $51: 7 \sim 25,1960$.

5) Furusho, T. : "Genetic study of stature", Jap. J. Human Genet., $19: 1 \sim 25,1974$.

6）腿部恒明：「身長飞伴亏身体諸测度の变異 1. 高

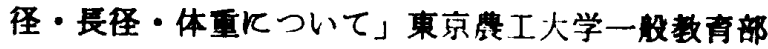
䄫要, $9(9), 1 \sim 23,1973$.

7）服部恒明，次木景甫：「18諴における身体諸经の 相対变異了人類学椎誌，79，337～346，1971.

8) Huxley, J. S. and G. Teissier : "Terminology of relative growth", Nature, 137:780 781, 1936. 9）岩本光雄, 北川 浩：「成人上下肢の非対称度に 闺する生体計則学的知見」人類学報，21：51～56,
1958.

10）腾木新次，那珂通矩，芝山秀太郎，細川浡一，江 橋博，浅野均一，小山淡一，辰野広吉，金子国吉：

「K大学および $\mathbf{K}$ 高校体育会各部の部貝の体格之体 力（第1報）」体力研究，7，147〜168，1965.

11）小林幸治良：「高等学校 Sports 買手の体格」体 育学研究, 12, 123〜131, 1968.

12) Montoye, H. J., G. E. Howard and J. H. Wood: "Observations of some hemochemical and anthropometric measurements in athletes", J. Sports Med. and Physical Fitness, $7: 35 \sim 44$, 1967.

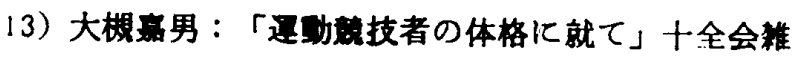

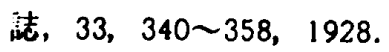

14) Pere, S., M. Kunnas and A. Telkkä : “Correlation between performance and physique in Finnish athletes", Am. J. Phys. Anthrop., 12 : $201 \sim 208,1954$.

15) Polednak, A. P.: "Secular trend in body size among college athletes", Am. J. Phys. Anthrop., $42: 501 \sim 506,1975$.

16) Schreider, E.: "Body-height relative variation studied on 839 adult male samples", Am.

J. Phys. Anthrop., $28: 223 \sim 226,1968$.

17）清水三堆：「人類に㧍ける Allomorphosis の研 究 (予報)」信州医学整誌，6，33～34，1957.

18）清水三堆：相对成長，共同医鱼出版社，1959.

19）下条 久：「スポーツ要手の体格について」生物 较計学椎誌, 6, 150 154, 1959.

20）白井伊三郎：「アジア親技大会蛽手の体勢火就い て」体力科学, 8, 287〜295, 1959.

21) Tanner, J. M. : "The effect on weight-training on physique", Am. J. Phys. Anthrop., 10:427 $461,1952$.

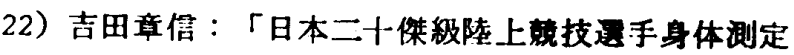
成精並に之に基く所謂「スポーツ体型」の研究(1)」 体育研究， 1，529 553， 1933. 